B I O S C I E N C E

J O U R N A

\title{
KNOWLEDGE, ATTITUDE AND PRACTICES OF BIOMEDICINE STUDENTS ON THE PAPANICOLAOU EXAM
}

\section{Camila Aparecida Pinheiro Landim ALMEIDA ${ }^{1}$ (i) , Amanda Dias OLIVEIRA ${ }^{2}$ (D),} Lorena Mayra Alves ARAÚJO² (D) Antonio Luiz GOMES JÚNIOR² (D), Herica Emilia Félix de CARVALHO ${ }^{3}$ (D), Eliana Campêlo LAGO ${ }^{4}$ (i) , Adélia Dalva da Silva OLIVEIRA ${ }^{5}$ iD), Luana Kelle Batista MOURA ${ }^{5}$ iD

\footnotetext{
${ }^{1}$ Institute of Health Sciences, Universidade Católica Portuguesa, Porto, Portugal.

2 Department of Biomedicine, UNINOVAFAPI University Center, Teresina, Piauí, Brazil.

3 Postgraduate Program in Fundamental Nursing, University of São Paulo, Ribeirão Preto, São Paulo, Brazil.

${ }^{4}$ Department of Health Sciences, State University of Maranhão, Caxias, Maranhão, Brazil.

${ }^{5}$ Professional Master's Program in Family Health, UNINOVAFAPI University Center, Teresina, Piauí, Brazil.
}

\section{Corresponding author:}

Camila Aparecida Pinheiro Landim Almeida

Email: clalmeida@porto.ucp.pt

How to cite: ALMEIDA, C.A.P.L, et al. Knowledge, attitude and practices of Biomedicine students on the Papanicolaou exam. Bioscience Journal. 2021, 37, e37025. https://doi.org/10.14393/BJ-v37n0a2021-44204

\begin{abstract}
Cervical cancer is the second type of cancer that most affects women, considered a serious public health problem, however it can be detected and treated early through the Pap smear. This research aimed to analyze the knowledge, attitude and practices of biomedicine students on the Pap smear. A cross-sectional study on Knowledge, Attitude and Practice (KAP), applied with 108 students, was carried out at a Higher Education Institution in Teresina, Piauí, Brazil. The data were collected through the months of February and March of 2018 with the application of a questionnaire. Statistical analysis was descriptive in terms of absolute and relative frequencies. Knowledge 72 (66.6\%) and attitude 76 (70.3\%) presented adequate levels regarding the examination. As for the practice, the percentage of suitability was of 37 academics (34.2\%) relatively not adequate. It was concluded that the students had adequate knowledge and attitude, but an inadequate practice, and the Papanicolaou test is required for the early screening and prevention of cervical cancer.
\end{abstract}

Keywords: Health Knowledge, Attitudes, Practice. Knowledge. Papanicolaou Test. Student Health. Uterine Cervical Neoplasms.

\section{Introduction}

In relation to neoplasias, cervical cancer (CC) is the fourth most frequent cancer in women with an estimated 570,000 new cases in 2018 representing 6.6\% of all female cancers. In 2018, 569,847 new cases and 311,365 deaths occurred worldwide (Bray et al. 2018). In Brazil, the number of new cases in 2018 was 16,298 and the number of registered deaths was 8,079 (World Health Organization 2019).

There was a drop-in mortality trends in the capitals and other municipalities in the South and Southeast regions of Brazil. However, in the Northern and Northeastern municipalities, the tendency is increasing, pointing out the need for attention to those places that are less economically privileged, where it brings people with a greater risk and less chances to reach public health services (Guerra et al. 2017).

Cervical cancer occurs due to a disordered replication of the epithelium that covers the organ, involving the underlying tissue and may affect other organs. Among the classes of invasive carcinomas of the uterine cervix, there are two main ones, according to the origin of the affected epithelium: epidermoid 
carcinoma, more incident type that damages the squamous epithelium and the adenocarcinoma, more rare type, where the glandular epithelium is affected (Castanon et al. 2016).

Pap smears are the most effective technique when performed as a CC screening method. This method has been used for more than 40 years and thus women should be instructed and encouraged to perform this practice in order to detect some infections and prevent this neoplasia, according to the Ministry of Health, if it is discovered in its initial phase, that is, when there is still no manifestation of symptoms, it has an enormous chance of cure due to the identification of its precursor lesions (Brasil 2016; Simanullang and Sitopu 2020).

Information about the knowledge, attitude and practice of women about the purpose of the Pap smear and its execution are very important for health teams. To know the local reality and use this data for the planning and elaboration of health actions that reduce the current morbidity and mortality rates due to this type of cancer. Women's lack of information on the benefits of Pap smear, low socioeconomic status, and cultural issues associated with poor health services, in part, indicate that over half of cases of cervical cancer are diagnosed at an advanced stage in Brazil, which reduces the chances of cure and results in high death rates due to this pathology (Renna Junior and Silva 2018).

Based on studies that depict CC with a high incidence in Brazil, despite presenting ways of early detection and treatment, it became important to highlight the relationship of the Pap smear as a great ally in monitoring the prevention and detection of this disease. Thus, this study aimed to analyze with the Biomedicine course students what knowledge, attitude and practice regarding the Pap test, since as future Biomedical and health professionals, they can serve to act in the promotion of cervical cancer health and prevention.

\section{Material and Methods}

Cross-sectional study, assessment of Knowledge, Attitude and Practice (CAP), developed in a private Higher Education Institution, in the Northeast region of Brazil.

The study population was composed of 178 students, regularly enrolled in the Biomedical Graduation Course. The sample calculation was performed for finite populations and the sample was stratified by periods. Twelve students were selected in the 1st period, 39 in the 3rd period, 25 in the 5th period, 13 in the 6 th period, 24 in the 7 th period and 10 in the 8 th semester, in which they were randomly selected using the table of random numbers, being numbered by the teacher's frequency diary (Mesquita and Matos, 2014). It is noteworthy that there was no class formation in the 2nd and 4th period of the course in the institution. Therefore, there was no participation of students from the respective periods.

Thus, the quantitative of the sample consisted of 123 biomedicine students, with the following inclusion criteria: to be regularly enrolled in the Biomedicine Course of the Institution of Higher Education and to be present at the IES in the period of data collection (February and March 2018). 10 students were excluded from the study for refusing to participate and 5 students were absent and/or were on health leave during the period of data collection. Therefore, 108 students participated in the study. Students were recruited through daily dissemination in all classrooms of the course.

Data collection was performed from February to March 2018. Structured forms were used for data collection, with articulated questions about the topic addressed. The application of the KAP survey was used, which dynamically evaluated the population's knowledge of the subject, their attitude towards the problem addressed and their practice through such an approach; besides a form for characterization of sociodemographic aspects.

For a current research, the CAP Survey model used in the study by Ribeiro et al. (2013) and the following definitions were defined for the adequacy or non-adequacy of the observed variables:

al) Adequate Knowledge: when the Biomedicine student has heard about an exam, when she was diagnosed with cervical cancer, and if she safely mentioned two tests that should be used before performing the exam.

a.II) Inadequate knowledge: when the Biomedicine student, despite having heard of the exam, did not know that it was to detect cervical cancer, and did not mention any necessary care before the exam. In addition, Biomedicine students who declared that they had never heard of the exam were also included. 
b.l) Adequate Attitude: when the Biomedicine student answered that she underwent the exam to detect CCU early and with the concomitance that she affirmed that it is a routine exam.

b.II) Inadequate Attitude: when the Biomedicine student answered that the exam was necessary to prevent of Sexually Transmitted Disease (STD), that such performance was hardly necessary or even unnecessary.

c.l) Adequate Practice: when the Biomedicine student performed the exam less than three years ago and scheduled an appointment to show the results.

c.II) Inadequate Practice: when the Biomedicine student performed the exam less than three years ago, but did not return to show the results; when it took place more than three years ago, despite having scheduled an appointment to show the results; when, in addition to being performed more than three years ago, he did not return to evaluate the results; or when the woman has never had such an exam.

For the organization of the data, a database was created in the Microsoft Excel Program, with double typing of the data, which were later imported into the SPSS Program "Statistical Package for the Social Science" (version 22.0 for Windows). Statistical analysis was descriptive in terms of absolute and relative frequencies. The results were presented by illustrative tables. It is noteworthy that the age group used was prepared according to national studies on the subject, which follow the guidelines of the Brazilian Institute of Geography and Statistics (IBGE) (Brasil 2019).

This research was approved by the Research Ethics Committee, under No. 2.434.059 on November 9, 2017, pursuant to Resolution 466/2012 of the National Health Council.

\section{Results}

As for the results, sociodemographic variables that interfere in the knowledge, attitude and practice about the Papanicolaou exam in biomedicine academics were presented.

Of the 108 participants in this study, the prevalent age group was 18 to 24 years old (87.04\%), with a mean age of 19 years, followed by adult women in the age range of 24 to 30 years (10.19\%), with an average age of 26 years. In relation to the marital status, the predominance was 103 (95.37\%) single women. The monthly family income presented data with a predominance of up to two minimum wages, 37 (34.26\%), followed by three minimum wages with a total of 31 participants $(28.70 \%)$ (Table 1$)$.

Table 1. Distribution of the socioeconomic variables of biomedicine academics (Teresina, PI, Brazil, 2018).

\begin{tabular}{|c|c|c|c|}
\hline Socioeconomic variables & & $\mathrm{n}$ & $\%$ \\
\hline \multirow{5}{*}{ Age } & \begin{tabular}{l|l|l|}
18 & 24
\end{tabular} & 94 & 87.04 \\
\hline & $24 \mid---30$ & 11 & 10.19 \\
\hline & $30 \mid----36$ & 1 & 0.93 \\
\hline & $36 \mid----42$ & 1 & 0.93 \\
\hline & 42 or more & 1 & 0.93 \\
\hline \multirow{4}{*}{ Marital status } & Single & 103 & 95.37 \\
\hline & Married & 4 & 3.70 \\
\hline & $\begin{array}{l}\text { Lives with } \\
\text { partner }\end{array}$ & 1 & 0.93 \\
\hline & $\begin{array}{l}\text { Less than } 1 \\
\text { wage }\end{array}$ & 15 & 13.89 \\
\hline \multirow{3}{*}{ Family income } & 2 wages & 37 & 34.26 \\
\hline & 3 wages & 31 & 28.70 \\
\hline & $\begin{array}{c}\text { More than } 3 \\
\text { wages }\end{array}$ & 23 & 21.30 \\
\hline \multirow{5}{*}{ Period of the course } & Don't know & 2 & 1.85 \\
\hline & 10 & 9 & 8.33 \\
\hline & 30 & 29 & 26.85 \\
\hline & 50 & 25 & 23.15 \\
\hline & 60 & 13 & 12.04 \\
\hline
\end{tabular}




\begin{tabular}{cccc} 
& 70 & 22 & 20.37 \\
Scholarship/Academic funding & 80 & 10 & 9.6 \\
& Yes & 38 & 35.19 \\
Type of Scholarship/Academic funding & No & 70 & 64.81 \\
& ProUni & 8 & 20.51 \\
& FIES & 21 & 53.85 \\
& Educa mais & 10 & 25.64 \\
\hline
\end{tabular}

Source: Direct source.

Regarding the knowledge that biomedicine scholars had about Papanicolaou preventive examination, $72(66.6 \%)$ presented adequate level. The main source of information that prevailed amongst the interviewees was from the health professionals, with a significant number of 70 students (64.8\%), in addition to the internet corresponding to 59 (54\%) and TV, 47 (43.5\%), as presented in table 2.

Table 2. Aspects of knowledge and main source of information about the Papanicolaou exam, of biomedicine academics ( $n=108$ ) (Teresina, PI, Brazil, 2018).

\begin{tabular}{ccc}
\hline Knowledge $(\mathrm{n}=108)$ & $\mathrm{n}$ & $\%$ \\
\hline Adequate & 72 & 66.6 \\
Source of information & & 43.5 \\
TV & 47 & 21 \\
Magazine & 23 & 26 \\
Friends & 29 & 64.8 \\
Heath Profissionals & 70 & 20.3 \\
Family & 22 & 8.3 \\
Radio & 09 & 54 \\
Internet & 59 & 22.2 \\
Folder & 24 & 8.3 \\
Others & 09 & \\
\hline
\end{tabular}

Source: Direct source.

When questioned about two precautions at least to be taken prior to the test, not being menstruated was cited by $77(71.2 \%)$ and sexual abstention 24 hours before the test, for 70 (64.8\%), representing the most cited amongst the participants. Only 13 students (12\%) reported not knowing or not remembering any type of care (Table 3).

According to the data obtained in the research, 76 students $(70.3 \%)$ presented with adequate attitude to the Papanicolaou examination. Based on the methodology applied, the participants reported that the test was necessary to prevent CC $(51.8 \%)$, in addition to being treated with the routine examination (34.2\%), as shown in table 3.

Table 3. Adequacy of the attitude and main objective for the accomplishment of the exam, by biomedicine academics $(n=108)$ (Teresina, PI, Brazil, 2018).

\begin{tabular}{ccc}
\hline Attitude $(\mathrm{n}=108)$ & $\mathrm{N}$ & $\%$ \\
\hline Adequate & 76 & 70.3 \\
What would lead to the examination & & 51.8 \\
Prevent CC & 56 & 24 \\
Detect STD / HIV or other pathologies & 26 & 6.4 \\
A health professional recommended & 07 & 34.2 \\
Rotine & 37 & - \\
Another cause & - & \\
\hline
\end{tabular}

Source: Direct source. 
It was also revealed that less than half of the participants of the study, 37 (34.2\%) had their practices considered adequate, prevailing the inadequacy of the practice before the exam. In view of this, the reasons presented for not doing so, in which 65 answers were obtained in this requirement, where the most prevalent was "physician was not requested", answered by 50 students (46\%) besides "shame for this type of execution" (9.2\%), "carelessness, not considering that the exam is of great importance" (3.7\%), and "the annoyance with the examination, so does not perform it periodically", $(0.93 \%)$, as presented in table 4.

Table 4. Adequacy of practice and reasons for not performing the Pap smear according to the biomedicine academics ( $n=108)$ (Teresina, PI, Brazil, 2018).

\begin{tabular}{ccc}
\hline Practice $(\mathrm{n}=108)$ & $\mathrm{N}$ & $\%$ \\
\hline Adequate & 37 & 34.2 \\
Reason for non-performance & 65 & 60.8 \\
Shame to take the exam & 10 & 9.2 \\
Do not think the exam is & 04 & 3.7 \\
of great importance & 01 & 0.93 \\
The exam bothers you, so do not do it & 50 & 46 \\
\hline
\end{tabular}

Source: Direct source.

The frequency of the examination was verified, and the interviewees revealed that 20 (18.52\%) underwent the preventive exam less than a year ago, $11(10.19 \%)$ one and two years ago and $6.48 \%$ did not remember the time, as shown in table 5.

Table 5. Periodicity of the preventive examination of the biomedicine academics $(n=108)$ (Teresina, PI, Brazil, 2018).

\begin{tabular}{ccc}
\hline Periodicity of exam realization & $\mathrm{N}$ & $\%$ \\
\hline Less than 1 year ago & 20 & 18.52 \\
1 year ago & 11 & 10.19 \\
2 years ago & 11 & 10.19 \\
3 years ago & 0 & - \\
More than 3 years ago & 0 & - \\
Can't recall & 7 & 6.48 \\
\hline
\end{tabular}

Source: Direct source.

\section{Discussion}

The survey of the biomedicine students' knowledge about the preventive examination was one of the essential factors to evaluate the strategies adopted in their prevention of the CC. The research presented adequate knowledge of 72 participants, demonstrating a good understanding regarding the examination. The results were consistent with the study by Iglesias et al. (2019), in which it was verified that a large part of the patients knew what the exam is and the purpose of the examination. However, research has shown that most of it the women use it as a means for the discovery and treatment of possible virginals.

A study carried out with 473 university students (Medicine, Nursing, Veterinary Medicine, Pharmacy, Dentistry, Biomedicine and Biology), as well as undergraduate courses in other areas of knowledge (Chemistry, Administration, Accounting, Computer Science and Mathematics) revealed that the Most students knew what the test was, as well as its frequency, however, 30.4\% were unaware of the meaning of an altered result, that is, as the questions became more complex, the level of knowledge on the subject decreased. It is important to highlight that, when comparing the knowledge of students in the health field with students from other areas, it was observed that those in health presented greater knowledge (Baptista et al. 2019).

Two studies carried out with nursing students, one in the Northeast region (Ribeiro et al. 2013) and another in the South region of Brazil (Silva et al. 2019), revealed that the students' knowledge was limited to specific notions about the theme, in addition to not knowing the real purpose of this exam. 
Health professionals portray a fundamental role in relation to guidelines on cytological examination, making women more self-confident and aware of the importance of the examination in their routine and health, increasing adherence to it, encouraged by prevention and not only by the yearning to acquire cancer. This factor was cited by 70 of the study participants as collaborators in the search for the exam. The internet was also considered as an information medium for other knowledge, cited by 59 participants.

The significance of the active search for the team present in primary health care is a role developed mainly by the community agent, through home visits or even through communication sources, such as the use of electronic devices. Moreover, educational skills should be valued and interventions that stimulate the health and well-being of women should be fundamental in the environments in which they are inserted (Lopes and Ribeiro 2019).

To complement the adequate knowledge of the study, participants were able to cite at least two of the care that must be taken before the examination, in which 77 students reported not being menstruated, 70 , answered no sexual intercourse 24 hours before the exam and 13 said they did not know or did not remember any care that should be taken. The lack of instruction can cause changes in the results, which may disrupt the methodology used, also complicating the reading of the slides, creating difficulties that may involve disagreements on the part of the client and the non-return to a new execution of the exam (Mendes et al. 2018).

Regarding the aspects that collaborated in the search for understanding and closer to the exam, part of the students mentioned that to prevent CC, 56, and to be an exam that is part of the routine, cited by 37 would be acts that would lead them to do it, being able to be compared to a study in which the result obtained from the same aspect was $89.3 \%$ of the participants recognize that they sought the cytological as a means of prevention of cancer having a complete understanding of the indispensability and significance of this attitude for their well-being and health (Silva et al. 2019).

According to the National Cancer Institute (Brasil 2016), the repetition of the examination is indicated every three years, then two normal tests obtained in a year. The achievement of one year after the first evaluation is intended to limit the chance of false negative results in this first stage and detection.

Early prevention with the practice of Pap smear, which transparently identifies changes in the cells that can cause CC, should be essential to practice often checking for lesions in up to $80 \%$ of cases. Regarding the practice of the study participants, only 37 reported having performed the procedure. These data differ from others two studies, nationals and internationals, which shows that more than half of the participants performed the test well after starting their sexual life (Mendes et al. 2018; Tsegaye et al. 2018).

The present study portrayed in the obtained data, students with average age of 19 years and single. Thus, a survey conducted in Guarapuava and Rio Grande do Sul, on the relation of the age group of women with the practicality of the exam was statistically significant, with a greater participation of participants aged 25 and 40 years. This fact attributed to correct practice with the age group because those who are of reproductive age practice more exams because they are directed to procedures that are part of the routine, even during prenatal and to be part of the family organization (Leite et al. 2014). Faced with the reasons that led the students to not take the exam, 50 reported that the doctor never asked for it and 10 for reasons of shame. Many women, especially those of young age, only seek medical attention when they realize that there is something strange in their body with the presence of symptoms that are not part of their daily routine and proper health. The medical recommendation may refer to the gynecological laments that cause them to consult, and with this, the doctor asks that the exam be performed not only to prevent CC, but as a strategy, to guide the patient's specific treatment of the symptoms.

The feeling of shame is attributed to several women, making it an impediment for them to make decisions on the test. The visualization of the body throughout the procedure can cause the patient to not feel relaxed causing it to become painful and at the same time unpleasant, this makes it immobilized to such an action so that there is loss of the correct positioning for the collection and the non-attendance to the next cytological exams.

Regarding the period of the examination, 20 of the interviewees performed less than one year, 11 one and two years and 7 did not remember the time of achievement. In fact, there is a shortage of the periodicity of the students in relation to the preventive examination, which can complicate the supervision and the correct screening of these women presenting improper practice about the Papanicolaou exam. 
The limitations of this study have to do with the design itself that does not allow us to make a deeper approach to the participants and / or follow-up, mainly to evaluate what could be done to change the improper practice of not taking the exam, even knowing its importance. Another limitation was the refusals of the participants and the restriction of access to information, even when the researchers informed about the confidentiality of the information. However, there were relevant results related to the students' adequate knowledge and attitudes and, mainly, by revealing the participation of health professionals as an information vehicle, contributing to the early screening, prevention and control of cancer.

\section{Conclusions}

According to the objective outlined, biomedicine students presented adequate knowledge and adequate attitude on the Papanicolaou preventive examination, besides knowing not only how they should be conducted prior to their accomplishment, but also its purpose. The health professionals were cited as great means of information regarding the examination, which pass on necessary guidelines and selfconfidence for women, so that they can become aware and perform it periodically for the control and prevention, and early cancer screening, by doing so, part of the established routine. On the other hand, the participants presented an inadequate practice, although they know what the Pap smear is and what it is for, with reasons for not doing the exam, such as shame and not asking the doctor.

Authors' Contributions: ALMEIDA, C.A.P.L.: conception and design, acquisition of data, analysis and interpretation of data, drafting the article; OLIVEIRA, A.D. and ARAÚJO, L.M.A.: acquisition of data, analysis and interpretation of data, drafting the article; GOMES JÚNIOR, A.L. and CARVALHO, H.E.F.: analysis and interpretation of data, drafting the article; LAGO, E.C.; OLIVEIRA, A.D.S. and MOURA, L.K.B.: drafting the article. All authors have read and approved the final version of the manuscript.

Conflicts of Interest: The authors declare no conflicts of interest.

Ethics Approval: Approved by Research Ethics Committee of UNINOVAFAPI University Center. Number: 2.434.059.

Acknowledgments: Not applicable.

\section{References}

BAPTISTA, A.D., et al. Knowledge of human papillomavirus and Pap test among Brazilian university students. Revista da Associação Médica Brasileira. 2019, 65(5), 625-32. https://doi.org/10.1590/1806-9282.65.5.625

BRASIL.V Pesquisa Nacional de Perfil Socioeconomico e Cultural dos (as) graduandos (as) das IFES - 2018. Brasília: FONAPRACE, 2019. Available from: https://www.andifes.org.br/wp-content/uploads/2019/05/V-Pesquisa-do-Perfil-Socioecon\%C3\%B4mico-dos-Estudantes-deGradua\%C3\%A7\%C3\%A3o-das-Universidades-Federais-1.pdf

BRASIL. Diretrizes brasileiras para o rastreamento do câncer do colo do útero. 2a ed. Rio de Janeiro: INCA; 2016.

BRAY, F., et al. Global cancer statistics 2018: GLOBOCAN estimates of incidence and mortality worldwide for 36 cancers in 185 countries. CA: A Cancer Journal for Clinicians. 2019, 68(1), 394-424. https://doi.org/10.3322/caac.21492

CASTANON, A., LANDY, R. and SASIENI, P.D. Is cervical screening preventing adenocarcinoma and adenosquamous carcinoma of the cervix? International Journal of Cancer. 2016, 139(1), 1040-5. https://doi.org/10.1002/ijc.30152

GUERRA, M.R., et al. Magnitude e variação da carga da mortalidade por câncer no Brasil e Unidades da Federação, 1990 e 2015. Revista Brasileira de Epidemiologia. 2017, 20(1), 102-15. http://dx.doi.org/10.1590/1980-5497201700050009

IGLESIAS, G.A., et al. Conhecimento e adesão ao Papanicolau de mulheres de uma rede de atenção primária à saúde. Revista de Ciências Médicas. 2019, 28(1), 21-30. http://dx.doi.org/10.24220/2318-0897v28n1a4008

LEITE, M.F., et al. Conhecimentos e prática das mulheres sobre câncer de colo do útero de uma unidade básica de saúde. Revista Brasileira de Crescimento e Desenvolvimento Humano. 2014, 24(2), 208-13.

LOPES, V.A.S. and RIBEIRO, J.M. Fatores limitadores e facilitadores para o controle do câncer de colo de útero: uma revisão de literatura. Ciência e Saúde Coletiva. 2019, 24(9), 3431-42. https://doi.org/10.1590/1413-81232018249.32592017

MENDES, L.C., ELIAS, T.C., and SILVA, S.R. Conhecimento e prática do exame Papanicolaou entre estudantes de escolas públicas do período noturno. Revista Mineira de Enfermagem. 2018, 22(1), 1-17. https://doi.org/10.5935/1415-2762.20180009

MESQUITA, R.F. and MATOS, F.R.N. A abordagem qualitativa nas ciências administrativas: aspectos históricos, tipologias e perspectivas futuras. Revista de Ciências da Administração. 2014, 5(1), 7-22. https://doi.org/10.6008/SPC2179-684X.2014.001.0001 
RENNA JUNIOR, N.L. and SILVA, G.A. Temporal trend and associated factors to advanced stage at diagnosis of cervical cancer: analysis of data from hospital based cancer registries in Brazil, 2000-2012. Revista Epidemiologia e Serviços de Saúde. 2018, 27(2), 1-12.

http://dx.doi.org/10.5123/s1679-49742018000200003

RIBEIRO, K.F.C., et al. Conhecimento, atitude e prática de acadêmicas de enfermagem sobre o exame de papanicolaou. Texto \& Contexto Enfermagem. 2013, 22(2), 460-7. http://dx.doi.org/10.1590/S0104-07072013000200023

SILVA, R.G.M.da, et al. Teste de Papanicolau: realização e conhecimento de acadêmicas de enfermagem. Revista de Epidemiologia e Controle de Infecção. 2019, 9(1), 1-8. http://dx.doi.org/10.17058/reci.v9i1.11592

SIMANULLANG, R.H., and SITOPU, S.D. Effect of Health Education on Women's Knowledge Level about Pap Smear's Early Detection of Cervical Cancer Prevention. Asian Journal of Oncology. 2020, 1(1), 1-46. http://dx.doi.org/10.1055/s-0040-1709365

TSEGAYE, S., MENGISTU, D. and GULTIE, T. Knowledge and attitude towards cervical cancer screening and associated factors among female Hawassa university college of Medicine and health sciences students. MedCrave Online Journal of Public Health. 2018, 7(3), 151-158. https://doi.org/10.15406/mojph.2018.07.00221

World Health Organization. The Global Cancer Observatory. France: WHO, 2019. Available form: https://gco.iarc.fr/

Received: 29 August 2018 | Accepted: 18 June 2020 | Published: 10 June 2021

This is an Open Access article distributed under the terms of the Creative Commons Attribution License, which permits unrestricted use, distribution, and reproduction in any medium, provided the original work is properly cited. 